\title{
The Analysis of Quality Control in Garment Company Using Statistic in Controling Product
}

\author{
N. Mayang, T.A.Koeswandi, S.Yulianti \\ Universitas Pendidikan Indonesia \\ Bandung, Indonesia \\ nafila.mayang@student.upi.edu
}

\begin{abstract}
Garment Company is a company engaged in the manufacture of garments such as pants, t-shirts, shirts and others. In order to maintain consumer confidence to produce a quality product, the company used a sampling technique with International standards by suppressing high defect products. In fact, the average defect rate of convection in various company products was about $29-32 \%$ in the period of September 2014 . This study aimed to determine the implementation of quality control by using statistical tools which can be useful to control the level of disability products in the company, know the type of disability dominant, and provide solutions for problems facing by the company. This study used descriptive method. Analysis of the quality control was used by using statistical tools such as Pareto diagrams, maps $u$ control, causal diagram and the tree diagram. The result of Pareto analysis diagram showed that major types of rejected products were defect clothes $(31.53 \%)$, broken $(28.40 \%)$, and disability accessories $(\mathbf{2 0 . 9 8 \%})$, however the dominant type of defect was the defect of fabric. Based on the analysis of the control $u$ map, it showed that there were still samples outside the control limits; they were sample on $22^{\text {nd }}$ and $28^{\text {th }}$. From the analysis of causal diagram, it can be concluded that disability products were derived from working methods, human/labor, materials/raw materials, and machinery. To add, the visible raw materials became the main factor causing the fabric defect.
\end{abstract}

Keywords-quality control, statistical tools, Tree diagram.

\section{INTRODUCTION}

Quality control is required to maintain the product in accordance with the applied standardization. Quality control in a company can't be run properly without any supporting notion from the complete information. The company needs to find a way to find information regarding the quality control. The quality control activity will help the company to maintain and increase in controlling the defected product level until zero defected level [1].

When quality control is held properly, it will give a good impact to quality of product. The standard of the quality consists of raw material, production process and final product [2]. Thus, controlling quality can be started from raw material when production process is holding until final product.

Quality control relates with Total Quality Management (TQM). The most important tool TQM is Statistical Process Control $(S P C)$. SPC is a tools in the production processing and final product to reduce defects by identifying the highest waste is occur at and to give suggestion for improvement [3].

The use of statistic in quality control helps to monitor the efficient level. Thus, statistic can be treated as a tool to overcome the defection by rejecting and accepting several products that are produced by machine. By rejecting (accepting) product, it can also be a tool to monitor the production process in order to get the description and conclusion about specification product which produce in general population. If the description is good, it means the process production can produce in long term process [4]

To conclude, the quality control affects the production process in monitoring the defected product. It will cause the reduction of product value that has been produced and loss of benefits.

\section{QUALITY CONTROL}

Operation management is a set of activity that creates service and goods through change from input to output [5]. The activity of controlling is a part of management operation and it is essential in order to keep the company to run on the right track and reach the aimed goal. Controlling is an activity to monitor the activity and make sure that it is on the right planned procedure.

Quality control is a technique of operation and activity that is used to fulfill the quality requirement [6]. The aims of quality control, are as follows:

- To create a final production in the planned standardized quality.

- To attain the lowest budget inspection

- To attain the lowest budget of the design budget of product and process by using quality product.

To produce the lowest production budget.

Quality control that has been done by companies can be in a variety way such as doing whole inspection $(100 \%$ inspection) and doing statistically. Statistical quality control is a quality control that used qualitative and quantitative data. Statistical Quality Control (SQC) is a developed system to keep the uniform standard of output production by using minimum budget and applying assistance to get efficiency [7]. 
There are two tools of statistical quality control, as follows:

- Acceptances Sampling

- Statistical Process Control

Statistical Process Control is a quality control in production process. Statistical Process Control is an application from technique in process controlling statistic. Statistical Process Control is an effective powerful methodology for analyzing, monitoring, managing, and improving process performance [8].

There are seven main tools in quality control by using Statistical Process Control (SPC) and Statistical Quality Control (SQC), they are check sheet, histogram, control chart, diagram pareto, cause and result diagram, scatter diagram and process diagram [5].

The hypothesis in this study is quality control by using statistic tool can be treated as a tool to control and monitor the efficiency level. So that, it can be assumed as a tool to prevent the defection product by rejecting and accepting products created by machine.

It mean that by rejecting product, it would monitor the production process and get description of result about specification product in general population. If the description result is good, it means the production process can be continued [9].

\section{RESEARCH METHODOLOGY}

This research conducted in Garment Company was focused on quality control in pressing the level of deformity product.

This research used descriptive method. It is method aimed to get description about an object or describe the situation due to appeared factors in faced situation.

The population is the amount of denim pants in Garment Company in 2014 period. The sample is denim pants basic and fashion of October 2014 edition. The adequate data test used to figure out whether the data collected is sufficient. Then, the data were analyzed by using Diagram Pareto, controlling map $u$, Fishbone Chart, and Tree Diagram.

\section{RESUlTS \& DisCUSSIONS}

The adequacy test was used to find out the amount of the data were sufficient statistically [10], the formula used as follows:

$$
N^{\prime}=\frac{(Z)^{2} \times(\bar{u}) \times(1-\bar{u})}{(\alpha)^{2}}
$$

The amount of denim pants in October 2014 period was 75.975 pieces and there were 4.313-piece deformity pants. An adequate test was held. It showed that conviction level (Z) used was $99 \%$ and carefulness level used was $10 \%$. The calculation was:

$$
N^{s}=\frac{(3)^{2} \times 0,057 \times(1-0,057)}{(0.01)^{2}}=4837,49
$$

According to the calculation, it shows that $N$ value is smaller which is $4838<75.975$, it means that the sample is sufficient.

The pareto chart is a form of bar chart with each bar representing a cause of a problem and always arranged so that the most influential cause of a problem in descending order. this information is helpful in focusing attention on the highestpriority category [11].

The amount of intolerant deformity product in October 2014 period is explained below:

TABLE I. The FreQUENCY OF DEFORMITY IN OCTOBER 2014 PERIOD

\begin{tabular}{|l|l|l|l|l|}
\hline No. & \multicolumn{1}{|c|}{ Deformity } & Total & Percentage & $\begin{array}{c}\text { Cumulative } \\
\text { percentage }\end{array}$ \\
\hline 1 & Deformity of fabric & 1360 & $31.53 \%$ & $31.54 \%$ \\
\hline 2 & Perforated & 1225 & $28.40 \%$ & $59.95 \%$ \\
\hline 3 & $\begin{array}{l}\text { Deformity of } \\
\text { Accessories }\end{array}$ & 905 & $20.98 \%$ & $80.94 \%$ \\
\hline 4 & Skipp Stitch & 703 & $16.30 \%$ & $97.24 \%$ \\
\hline 5 & Others & 120 & $2.78 \%$ & $100.02 \%$ \\
\hline Total & $\mathbf{4 3 1 3}$ & $\mathbf{1 0 0 , 0 0 \%}$ & \\
\hline
\end{tabular}

According to the data, the diagram Pareto is formed.

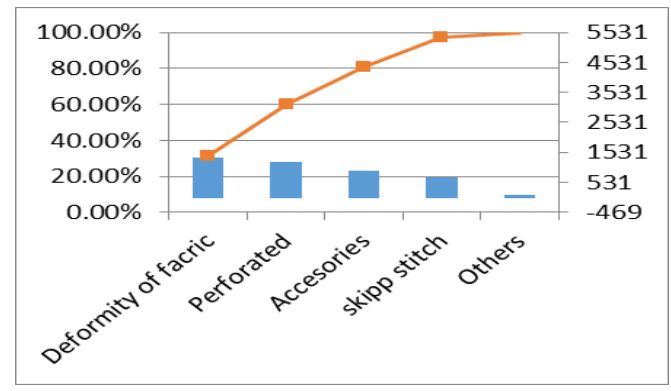

Fig. 1. Diagram Pareto Major Deformity

${ }^{\text {b. }}$ Resource: Result of Analysis

The U-map controlling was used to figure out whether any sample which is out of control [5]. The calculation is in the following form:

A. Calculating inappropriate per unit (u)

$$
C L=\bar{u}=\frac{\sum c}{\sum n}
$$

Subgroup 1:

$$
u=\frac{142}{2556}=0,055
$$

Subgroup 2:

$$
u=\frac{110}{1980}=0,056
$$




\section{AThNTIS \\ PRESS}

Subgroup 3:

$$
u=\frac{109}{1999}=0,055
$$

Subgrup 4:

$$
u=\frac{157}{2895}=0,054
$$

And so on...

B. Calculating Central Line (CL)

$$
C L=\frac{4313}{75975}=0,057
$$

C. Calculating Upper Control Limit (UCL)

$$
U C L=\bar{u}+3 \sqrt{\frac{u}{n}}
$$

Subgroup 1:

$$
U C L=0,057+3 \sqrt{\frac{0,057}{142}}=0,071
$$

Subgrup 2:

$$
U C L=0,057+3 \sqrt{\frac{0,057}{110}}=0,073
$$

Subgroup 3:

$$
U C L=0,057+3 \sqrt{\frac{0,057}{109}}=0,073
$$

Subgroup 4:

$$
U C L=0,057+3 \sqrt{\frac{0,057}{157}}=0,070
$$

And so on...

D. Calculating Lower Control Limit (LCL)

Subgroup 1:

$$
L C L=\bar{u}-3 \sqrt{\frac{u}{n}}
$$

$$
L C L=0,057-3 \sqrt{\frac{0,057}{142}}=0,43
$$

Subgroup 2:

$$
L C L=0,057-3 \sqrt{\frac{0,057}{110}}=0,041
$$

Subgroup 3:

$$
L C L=0,057-3 \sqrt{\frac{0,057}{109}}=0,041
$$

Subgroup 4:

$$
L C L=0,057-3 \sqrt{\frac{0,057}{157}}=0,043
$$

And so on...

The data then present in the table as follow:

TABLE II. CALCUlating LiMITED CONTROL OCTOBER 2014 PERIOD (IN UNIT)

\begin{tabular}{|c|c|c|c|c|c|c|}
\hline Day & Production & Deformity product & $\boldsymbol{u}$ & cl & ucl & Icl \\
\hline 1 & 2566 & 142 & 0,055 & 0,057 & 0,071 & 0,043 \\
\hline 2 & 1980 & 110 & 0,056 & 0,057 & 0,073 & 0,041 \\
\hline 3 & 1999 & 109 & 0,055 & 0,057 & 0,073 & 0,041 \\
\hline 4 & 2895 & 157 & 0,054 & 0,057 & 0,070 & 0,043 \\
\hline 5 & 3710 & 206 & 0,056 & 0,057 & 0,069 & 0,045 \\
\hline 6 & 2976 & 161 & 0,054 & 0,057 & 0,070 & 0,044 \\
\hline 7 & 1984 & 111 & 0,056 & 0,057 & 0,073 & 0,041 \\
\hline 8 & 2760 & 152 & 0,055 & 0,057 & 0,070 & 0,043 \\
\hline 9 & 1874 & 108 & 0,058 & 0,057 & 0,073 & 0,040 \\
\hline 10 & 2677 & 154 & 0,058 & 0,057 & 0,071 & 0,043 \\
\hline 11 & 1874 & 99 & 0,053 & 0,057 & 0,073 & 0,040 \\
\hline 12 & 1759 & 97 & 0,055 & 0,057 & 0,074 & 0,040 \\
\hline 13 & 2065 & 117 & 0,057 & 0,057 & 0,072 & 0,041 \\
\hline 14 & 2578 & 148 & 0,057 & 0,057 & 0,071 & 0,043 \\
\hline 15 & 2953 & 158 & 0,054 & 0,057 & 0,070 & 0,044 \\
\hline 16 & 1567 & 89 & 0,057 & 0,057 & 0,075 & 0,039 \\
\hline 17 & 1685 & 93 & 0,055 & 0,057 & 0,074 & 0,039 \\
\hline 18 & 1876 & 105 & 0,056 & 0,057 & 0,073 & 0,040 \\
\hline 19 & 1676 & 97 & 0,058 & 0,057 & 0,074 & 0,039 \\
\hline 20 & 1893 & 106 & 0,056 & 0,057 & 0,073 & 0,040 \\
\hline 21 & 2083 & 117 & 0,056 & 0,057 & 0,072 & 0,041 \\
\hline 22 & 3874 & 281 & 0,073 & 0,057 & 0,068 & 0,045 \\
\hline 23 & 3563 & 175 & 0,049 & 0,057 & 0,069 & 0,045 \\
\hline 24 & 2856 & 158 & 0,055 & 0,057 & 0,070 & 0,043 \\
\hline 25 & 1991 & 108 & 0,054 & 0,057 & 0,073 & 0,041 \\
\hline 26 & 1874 & 106 & 0,057 & 0,057 & 0,073 & 0,040 \\
\hline 27 & 3544 & 197 & 0,056 & 0,057 & 0,069 & 0,045 \\
\hline 28 & 3987 & 282 & 0,071 & 0,057 & 0,068 & 0,045 \\
\hline 29 & 3761 & 203 & 0,054 & 0,057 & 0,068 & 0,045 \\
\hline 30 & 3095 & 167 & 0,054 & 0,057 & 0,070 & 0,044 \\
\hline $\mathbf{2}$ & $\mathbf{7 5 . 9 7 5}$ & $\mathbf{4 . 3 1 3}$ & & & & \\
\hline
\end{tabular}

c. Resource: Result Analysis

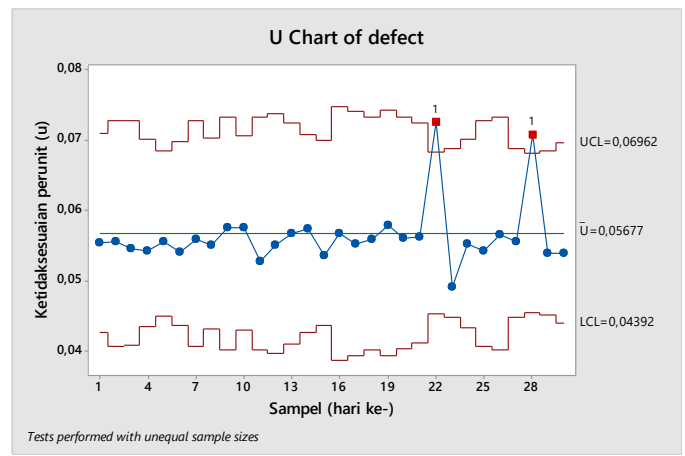

Fig. 2. Controlling Map $u$ denim pants in October 2014 Period

d. Resource: Analysis Result

According to $u$ controlling map, it is stated that the ucl is 0,070 ; $\mathrm{cl}$ is 0,057 and $\mathrm{lcl}$ is 0,044

Meanwhile the average of inappropriate product $(u)$ in each subgroup in the first day is 0,055 ; second day is 0,056 ; third day is 0,055 and so on. Until the twenty second sample 


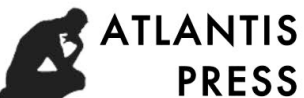

which is 0,073 and the twenty eighth which is 0,071 , they are over the limited controlling standard (outliner). Thus, it needs an equality to stay the sample in the limited controlling.

According to Pareto diagram, the most deformity product is the deformity of fabric. It becomes the main concern that needs to be fixed. In doing so, the cause-effect diagram is used to show the relation between the problem faced and the cause or the factors affected, such as:

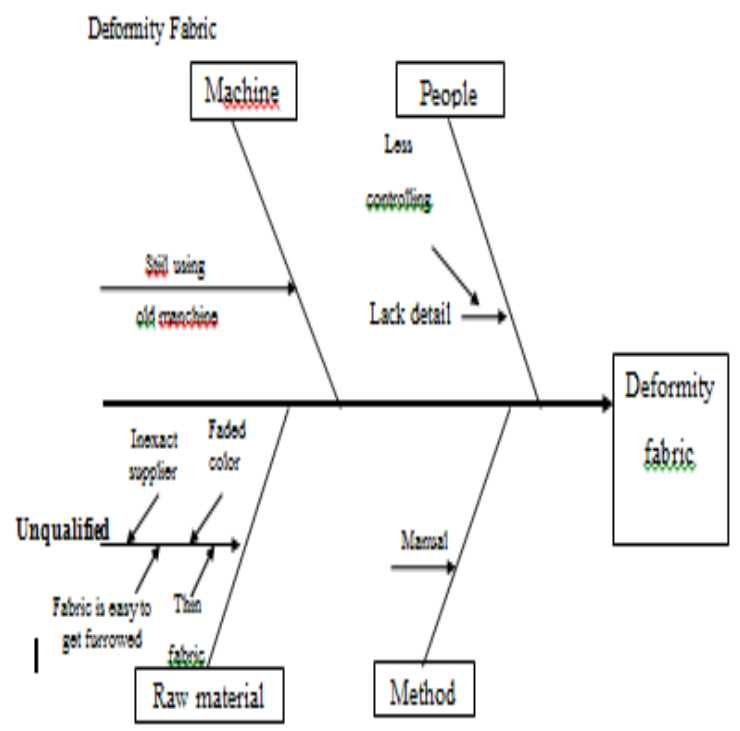

Fig. 3. The Cause-effect diagram of deformity fabric

e. Resource: Result Analysis

The deformity of fabric is caused by the lack of raw material quality; thus tree diagram is needed to overcome the problem. The diagram is as follow:

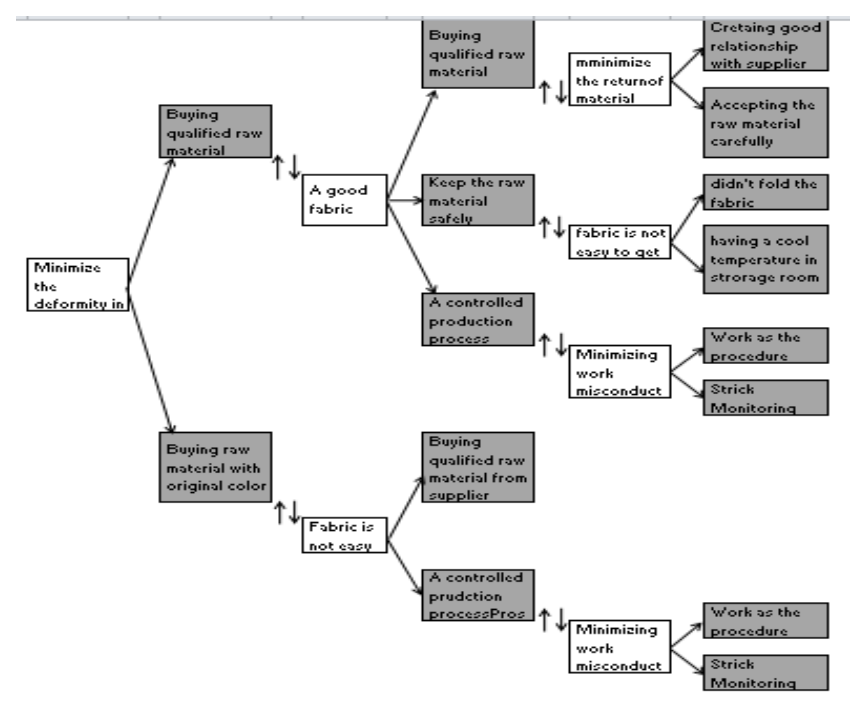

Fig. 4. Tree Diagram Raw Material

f. Resource: Result Analysis

According to the picture 4 , the most dominant problem is deformity of fabric, thus the solutions for this situation are:
1) Buying raw material in supplier which provides a good quality of raw material.

It will help the company to reduce the deformity and return the deformity fabric to the supplier. In doing so, the company needs to build a good relationship with the supplier. To add, company needs to check the raw material first when it arrived from the supplier.

2) Saving the raw material in a good storage place.

Raw material needs to be saved in a good place and right way especially for some fabric contains stretch, the company doesn't need to fold it. The folding will lead the fabric into furrowed. If this happens, the raw material isn't suitable with the standard fabric.

\section{3) The controlling production process.}

The controlling production process needs to be motorized in order to detract the mistake while producing process. The producing process is monitored by producing due to the quality control (QC).

Buying the original color of raw material is the act to overcome the faded away color of fabric. In washing the fabric, Garment Company can have done these steps:

1. Buying raw material in supplier which provides a good quality of raw material.

This can be done to overcome the deformity caused by faded color fabric caused by the lack of quality.

\section{The controlling production process.}

The controlling production process is done to overcome the mistake and keep the production on the right track, so that, the deformity products can be reduced.

\section{CONCLUSIONS}

The use of SPC technique as Quality Control in Garment Company has an important role in improving quality control. The use of SPC can be treated as a tool for the Operator and Management staff in doing faster improvement.

The quality control used by Garment Company shows that it has a good concept. It is shown by the use of sample which leads the company to minimize the time and cost. However, Garment Company still has lack of the implementation of the quality control shown by amount of defect product around 29-32\%. According to Pareto Diagram, the main improvement needed is to suppress the defect product which is $30,9 \%$ meanwhile the rest is affected by perforated which is $28,4 \%$, accessories defect $18,6 \%$, skip stitch $16,4 \%$ and others is $5,6 \%$. Fabric defect can affect to another defection. By using the statistic tools $u$ map control, it can identify that the process was in control in doing the uniformity, thus all sample were in the control line. There were two outliner, they were sample day $22^{\text {nd }}$ and $28^{\text {th }}$.

Due to the diagram analysis cause and effect, it can be seen that the factors of defect product are man, machine, method and material factors. Material is dominated the defect product which leads into unqualified product. 


\section{SUGGESTIONS}

The company needs to use the statistic method to know the type of damage and its factors. So that, the company can do the preventive action to overcome the deformity. According to the analysis by using the statistic, the company can do the improvement in terms of quality by focusing on the damage raw material which has large amount or dominant production.

Generally, the main cause of deformity is raw material factor. It is due to the monitoring activity on damaged in denim pants before and after production. Thus, to overcome this activity, there are several ways can be done such as:

- Choosing supplier which has a qualified raw material such as clean, the color is not easily to fade, and firm fabric.

- The company needs to focus on the saving process especially raw material contains of stretch material.

Process production is needed to control so that the human resource can work as the standard procedure.

\section{REFERENCES}

[1] Arifianti, Ria. 2013. "Analisis Kualitas Produk Sepatu Tomkins". Jurnal Dinamika Manajemen, Vol. 4, No. 1, Maret 2013.

[2] Nasution, M. N. 2005. "Manajemen Mutu Terpadu”. Bogor : Ghalia Indonesia.

[3] Y. Mengesha, A. P. Singh, and W. Yimer, "Quality improvement using statistical process control tools in glass bottles manufacturing company," Int. J. Qual. Res., vol. 7, no. 1, pp. 107-126, 2013.

[4] Fakhri, Al Faiz. 2010. “Analisis Pengendalian Kualitas Produksi di PT. Masscom Grahpy Dalam Upaya Mengendalikan Tingkat Kerusakan Produk Menggunakan Alat Bantu Statistik". Accessed on $13^{\text {th }}$ Oktober 2014, dari www.google.com/Jurusan Manajemen FE Undip.

[5] Heizer, Jay and Barry Render. 2006. "Operations Management (Manajemen Operasi)". Jakarta : Salemba Empat.

[6] Gasperz, Vincent. 2005. "Total Quality Management”. Jakarta: PT. Gramedia Pustaka Utama.

[7] Assauri, Sofjan. 2004. "Manajemen Produksi dan Operasi”. Edisi Revisi. Lembaga Penerbit Fakultas Ekonomi Universitas Indonesia. Jakarta.

[8] A. Mostafaeipour, A. Sedaghat, and A. Hazrati, "The use of Statistical Process Control Technique in the Ceramic Tile Manufacturing : a Case Study," vol. 2, no. 5, pp. 14-19, 2012.

[9] Prawirosentono, Suyadi. 2007. "Filosofi Baru Tentang Manajemen Mutu Terpadu Abad 21 Kiat Membangun Bisnis Kompetitif'. Jakarta : Bumi Aksara.

[10] Hasni, R Asysyfa; Tahir, Suharto \& Bakhtiar, S. 2013. "Analisa Pengendalian Kualitas Dengan Menggunakan Metode Statistical Quality Control (SQC)". Malikussaleh Industrial Engineering Journal, Vol. 2, No. 1.

[11] A. Co, H. Vardin, and K. B. Beliba, "Improvement of Food Safety and Quality by Statistical Process Control ( SPC ) in Food Processing Systems : A Case Study of Traditional Sucuk ( Sausage ) Processing," Qual. Control Herb. Med. Relat. Areas Ed. by Prof. Yukihiro Shoyama, 2011. 